\title{
Stage IIIB Lung Small Cell Carcinoma with Pleural Effusion AJCC v7
}

National Cancer Institute

\section{Source}

National Cancer Institute. Stage IIIB Lung Small Cell Carcinoma with Pleural Effusion AJCC v7. NCl Thesaurus. Code C35756.

Stage IIIB small cell lung carcinoma that has spread to the pleural fluid. 